\title{
O TRANSPLANTE DAS INTERPRETAÇÕES PREJUDICIAIS PARA O TRIBUNAL DE JUSTIÇA ANDINO
}

\section{EL TRASPLANTE DE LAS INTERPRETACIONES PREJUDICIALES PARA EL TRIBUNAL DE JUSTICIA ANDINO}

Cynthia Soares Carneiro*

Resumo: O estudo insere-se no novíssimo ramo do Direito de Integração Regional, ainda em processo de construção na América Latina, e tem como objetivo analisar os efeitos do transplante jurídico do instituto das Interpretações Prejudiciais do Direito Comunitário Europeu para a Comunidade Andina de Nações. Através do método de estudo de caso foram analisadas duzentas e oitenta e cinco decisões proferidas pelo Tribunal de Justiça Andino, escolhidas aleatoriamente dentro da ordem cronológica de julgamento, para identificar a natureza da ação originária, o tribunal nacional suscitante e as partes na demanda, buscando identificar especificidades do instituto americano em relação ao europeu e sua contribuição para o desenvolvimento da cooperação jurídica vertical e do direito de integração na América do Sul. Apesar de algumas diferenças pontuais, que serão analisadas no artigo, o resultado da investigação aponta para a necessidade de ponderar acerca da relevância dos tribunais comunitários à luz do princípio da subsidiariedade, que prioriza a atuação das instituições nacionais em detrimento das instituições de integração regional, bem como os efeitos econômicos dessas decisões frente à posição que os Estados sul-americanos ocupam no Moderno Sistema-mundo/ colonial.

Resumen: El estudio es parte de la nueva rama del derecho de integración regional, todavía en proceso de construcción en América Latina, y tiene como objetivo analizar los efectos del trasplante jurídico del Instituto de las Interpretaciones Prejudiciales del Derecho Comunitario Europeo para la Comunidad Andina de Naciones. A través del método de estudio de caso fueron analizadas doscientos ochenta y cinco decisiones emitidas por el Tribunal de Justicia Andino, elegidas en forma aleatoria dentro

* Universidade de São Paulo. Faculdade de Direito de Ribeirão Preto, Brasil.

E-mail: cynthia.carneiro@usp.br

Recebido: 23/07/2014. Aceito: 8/07/2016. 
de un orden cronológico de juzgamiento para identificar la naturaleza de acción originaria, el tribunal nacional causante y las partes en la demanda, buscando identificar especificaciones del instituto americano en relación al europeo y su contribución para el desarrollo de la cooperación jurídica vertical y del derecho de integración en América del Sur. A pesar de algunas diferencias puntuales, que serán analizadas en el artículo, el resultado de la investigación apunta a la necesidad de ponderar acerca de la pertinencia de los tribunales comunitarios a la luz del principio de subsidiaridad, que prioriza la actuación de las instituciones nacionales en detrimento da las instituciones de integración regional, bien con los efectos económicos de esas decisiones frente a la posición que los Estados sudamericanos ocupan en el moderno sistema/mundo colonial.

Palavras-chave: Cooperação jurídica vertical, Interpretação prejudicial, Tribunal Comunitário, Subsidiariedade, Transplante jurídico

Palabras clave: Cooperación jurídica vertical, Interpretaciones pre judiciales, Tribunal Comunitario, Subsidiariedad, Transplante jurídico

\section{INTRODUÇÃO}

O propósito deste artigo é compartilhar reflexões acerca da integração regional na América do Sul e sobre o processo judicial comunitário, especialmente relativo às Interpretações Judiciais, procedimento próprio desse novíssimo ramo que é o Direito de Integração Regional.

Essas análises são fruto de estudo de casos realizados para averiguar o objeto de pedir das Interpretações Prejudiciais, espécie própria de cooperação jurídica vertical, estabelecida entre juízes nacionais e comunitários, proferidas pelo Tribunal de Justiça da Comunidade Andina (TJA).

Esperava-se encontrar nessas decisões, indicativos sobre procedimentos de cooperação jurídica internacional, tanto horizontal como vertical, e a materialização de conceitos e de práticas próprias aos tribunais sul-americanos, a caracterizar um modo alternativo de funcionamento dessas instituições, em relação órgãos europeus dos quais o modelo foi literalmente transplantado.

A intenção era avaliar, por meio de suas Interpretações Prejudiciais, a contribuição do Tribunal de Justiça Andino (TJA) ao desenvolvimento de um direito comunitário próprio na região, tal como ocorrera no Tribunal de Justiça da União Europeia, onde esse procedimento de cooperação entre tribunais nacionais e o tribunal supranacional foi fundamental para a construção e consolidação do direito comunitário europeu. 
Mesmo que as instituições andinas, mais que as do MERCOSUL, tenham optado por transplantar o modelo de processo comunitário do Tribunal de Justiça Europeu, inclusive sua forma de cooperação jurídica vertical, através das Interpretações Prejudiciais, esperava-se encontrar caracteres próprios em relação ao modelo inspirador, justamente em face às especificidades da região, situada na periferia do sistema-mundo moderno ${ }^{1}$. No entanto, em relação ao aspecto formal e delimitação de conceitos jurídicos, não foi possível detectar procedimentos diferenciados.

No estudo não foi estabelecido um limite para a consulta de casos, pois seria necessário realizar uma análise exploratória para identificar a natureza dos questionamentos provocados pelos juízes nacionais ao Tribunal de Justiça Andino e os sujeitos na ação originária proposta, com fundamento no direito comunitário andino, perante os juízes locais. Como resultado da investigação também seria possível apurar o estado da arte da cooperação jurídica vertical na região andina. Foram consultadas, aleatoriamente e seguindo a ordem cronológica, 285 decisões, proferidas entre 1987 a 2012 e em um universo de mais de 2000.

Estas decisões encontravam-se, até 2014, inteiramente disponíveis na página oficial do TJA ${ }^{2}$, organizadas de forma cronológica. Atualmente, somente podem ser acessadas por meio do número do procedimento.

Como será relatado, todos os objetivos da investigação foram alcançados. Não do alcance do que era esperado, mas, mais que as evidências empíricas, a análise permitiu identificar com clareza o telos dos projetos de integração sul-americano, especialmente o andino, que foi objeto deste estudo, frente ao sistema internacional de mercados e de Estados: a permanência da histórica hierarquia colonial estabelecida pelo sistema-mundo moderno.

\section{O PRINCÍPIO DA SUBSIDIARIEDADE COMO MARCO PARA A ANÁLISE}

O princípio da subsidiariedade tem sido construído, juridicamente, a partir da formação dos blocos econômicos regionais e sua função é, essencialmente, regular a distribuição de competências entre o organismo internacional e seus Estados-Membros. A partir da vigência do Tratado de Maastricht, os órgãos comunitários, dentre eles o Tribunal de Justiça europeu, e a academia tem avançado na delimitação de seu conteúdo e conceito.

Com raízes históricas no liberalismo e em sua análise das relações entre Estado e sociedade, o principio da subsidiariedade, atualmente, é

1 WALLERSTEIN, Immanuel. Capitalismo histórico e civilização capitalista. SP: Contraponto, 2001. 2 Disponível em: <http://www.tribunalandino.org.ec/sitetjcal/index.php>. [acesso em 10. fev. 2017]. 
entendido sob duas dimensões: a horizontal, que estabelece, justamente, os limites do Estado na ingerência sobre interesse privados, e a vertical, que determina restrições à atuação do ente público de maior instância, os órgãos comunitários, quando o ente público menor, ou seja, as instituições nacionais, puderem atuar de forma adequada e eficaz ${ }^{3}$.

Este é o significado etimológico da palavra, posto que subsidiariedade é a função de auxílio, de subsídio, do ente maior em relação ao menor, do Estado em relação à sociedade civil, da União em relação às unidades federadas, ou, finalmente, da Comunidade em relação aos Estados-Membros: quando a entidade de menor abrangência não puder desenvolver, de forma satisfatória, sua finalidade e objetivos, é auxiliada pela entidade de maior abrangência, que atua para suprir suas deficiências ${ }^{4}$.

A função de subsidiar, portanto, é inerente aos organismos internacionais voltados à promoção da integração regional e do desenvolvimento econômico local, e indissociável em relação aos seus Estados-Membros, que mantém, integralmente, a soberania e independência de suas instituições nacionais. Mesmo para as estruturas estatais vigentes, o princípio traz aspectos interessantes, justamente por repercutir na estrutura jurídico-administrativa do Estado, estabelecendo a descentralização institucional, inibindo, juridicamente, a atuação dos órgãos centrais em relação aos locais. Nesse sentido, fundamenta as reformas constitucionais que estabeleceram o Estado autonômico na Espanha e inspira reformas no mesmo sentido em outros Estados europeus e sul-americanos 5 .

Por isso, o princípio da subsidiariedade carrega elementos potencialmente revolucionários, pois promove mudanças significativas em características essenciais do Estado moderno, em relação ao exercício de sua soberania externa e na forma como são estruturados internamente. Neste sentido, representa a inversão da lógica governamental no processo de formação do Estado Nacional. Ao invés da concentração das instituições estatais e enfraquecimento do poder local, a descentralização jurídico-administrativa com a transferência de competências para unidades regionais menores para garantir, uma atuação eficaz, ou seja, capaz de dar respostas rápidas às demandas públicas, e adequada, atendendo tais demandas de maneira satisfatória ${ }^{6}$.

3 GABARDO, Emerson. Interesse público e subsidiariedade: o Estado e a sociedade civil para além do bem e do mal. São Paulo: Fórum, 2009, p. 212; e LÁZARO, Alicia Chicharro. El Principio de Subsidiariedad en la Unión Europea. Madrid: Aranzadi, 2001, p. 65.

4 QUADROS, Fausto de. O princípio da subsidiariedade no direito comunitário após o tratado da União Européia. Coimbra: Almedina, 1995; BARACHO, José Alfredo de Oliveira. “O princípio de subsidiariedade: conceito e revolução”. Revista de Direito Administrativo. 1995, p. 21-54.

5 MAGALHAES, J. L. Q. Pacto Federativo. Belo Horizonte: Mandamentos, 2002; e MAGALHÃES, José Luiz Quadros; ROCHA, Carlos Alberto Vasconcelos. O município e a construção da democracia participativa. Belo Horizonte: Mandamentos, 2006.

6 QUADROS, Fausto de. O princípio da subsidiariedade no direito comunitário após o tratado da 
Apesar de ser tratado por Aristóteles, Tocqueville e pelo Papa Leão XIII, naEncíclica Rerum Novarum ${ }^{7}$, o princípio da subsidiariedade somente adquiriu expressão normativa com a criação dos órgãos supranacionais da União Europeia, que, em seu processo de aprofundamento, encontrouse na contingência de regular os limites de sua atuação em relação aos Estados-Membros, de forma a não comprometer sua soberania originária ${ }^{8}$. Sua formalização, entretanto, tem induzido reformas na arquitetura institucional dos Estados, pela redistribuição de competências antes concentradas em órgãos da União, no caso dos Estados Federados, ou nos órgãos nacionais, nos Estados unitários, que passam a ser exercidas por entes sub-regionais e municipais.

Este fenômeno europeu tem sido transplantado para outros continentes, posto que o direito comunitário, nos moldes como foi instituído na União Europeia, tem sido transplantado, em maior ou menor grau, para todos organismos de integração regional existentes no globo. É o que podemos observar nos organismos de integração sul-americanos, especialmente na Comunidade Andina, formada por Estados que possuem os menores índices de desenvolvimento da região ${ }^{9}$.

O fato é que, a partir do século XVIII, quando se iniciam as lutas por emancipação colonial, instituições econômicas e jurídicas européias tornaram-se paradigma para os Estados recém-criados. Da mesma forma, no século XX, instituições comunitárias europeias foram, ao menos formalmente, transplantadas para os organismos de integração regional que se sucederam, evidenciado que, institucionalmente, os Estados Nacionais modernos estão vinculados a uma rede de relações político-econômicas que os inserem na sociedade internacional. Estas relações, desde então, têm sido estabelecidas segundo uma racionalidade ou funcionalidade hierárquica, fundada em Estados centrais e Estados periféricos, cujo efeito é a divisão internacional da produção e do trabalho, a materializar a concentração de renda tanto em âmbito mundial como local ${ }^{10}$.

Esta é a hipótese fundamental a orientar estes estudos sobre a integração comunitária e estabelecer sua problematização: quais

União Européia. Coimbra: Almedina, 1995; BARACHO, José Alfredo de Oliveira. “O princípio de subsidiariedade: conceito e revolução”. Revista de Direito Administrativo. 1995, p. 21-54.

7 QUADROS, Fausto de. O princípio da subsidiariedade. Op. cit.

$8 \mathrm{Na}$ Versão consolidada do Tratado da União Europeia (Tratado de Lisboa), o princípio da subsidiariedade esta expresso no seu art. $3^{\circ}$, n. 3: "Em virtude do princípio da subsidiariedade, nos domínios que não sejam da sua competência exclusiva, a União intervém apenas se, e na medida em que, os objetivos da ação considerada não possam ser suficientemente alcançados pelos Estados-Membros, tanto ao nível central como ao nível regional e local, podendo, contudo, devido às dimensões ou aos efeitos da ação considerada, ser mais bem alcançados ao nível da União". Disponível em: <http://eur-lex.europa.eu/LexUriServ/LexUriServ. do?uri=OJ:C:2010:083:0013:0046:PT:PDF> [acesso em 23.mar.2015].

9 A Comunidade Andina de Nações, anteriormente chamada Pacto Andino, é atualmente constituída pela Bolívia, Colômbia, Equador, Peru.

10 WALLERSTEIN, Immanuel. Op. cit. 
os verdadeiros beneficiários dos processos comunitários regionais? A quem interessa e quem diretamente se beneficia dos sistemas de integração sul-americanos? Uma vez estabelecidas, como se manifestam as instituições transplantadas do modelo europeu em um ambiente comunitário completamente diverso e de herança colonial?

Parece evidente que uma integração sul-americana baseada em um modelo assim concebido estaria fadada ao fracasso. Os objetivos institucionalmente declarados provavelmente jamais seriam atingidos. No entanto, nas duas últimas décadas, tanto a CAN como o MERCOSUL aumentaram consideravelmente sua atuação, o que pode ser dimensionado pela prodigiosa produção do Tribunal de Justiça Andino, o terceiro mais atuante dentre os tribunais internacionais existentes no mundo ${ }^{11}$.

Neste aspecto, o MERCOSUL, muito criticado, desde suas origens, por não seguir à risca, como fez a Comunidade Andina, o desenho institucional dos órgãos comunitários europeus, representaria um modelo alternativo aos organismos de integração? $\mathrm{O}$ artigo propõe essa questão.

\section{TRANSPOSIÇÕES INSTITUCIONAIS E RACIONALIDADE DO SISTEMA-MUNDO/COLONIAL: UMA METODOLOGIA DE ANÁLISE}

Considerando que a transposição de normas europeias por Estados da América Latina ocorre desde a origem destes Estados, o fenômeno do transplante jurídico trata-se de aspecto funcional do sistema-mundo/colonial. A partir desta constatação, analisamos o resultado materializado pelas instituições comunitárias sul-americanas para averiguar os efeitos destes transplantes normativos, apurando se a atuação destas instituições leva a resultados que correspondem aos interesses integracionistas declarados nos seus tratados constitutivos ou se seus resultados atendem aos históricos interesses de companhias localizadas em Estados centrais ao sistema-mundo, estabelecendo seus aspectos de colonialidade.

Para analisar este resultado institucional foram examinadas decisões proferidas pelo Tribunal de Justiça Andino (TJA). Aliás, o órgão judicial da CAN é o que melhor traduz a literal transposição do direito comunitário europeu para a América do Sul. Além disso,

11 HELFER, Laurence R. ALTER, Karen; GUERZOVICH, Florencia. "Islands of effective international adjucation: constructing an intellectual property rule of law in the Andean Community". The American Journal of International Law. 2009, vol 103, n 1; e ALTER, Karen; HELFER, Laurence R.; SALDÍAS, Osvaldo. "Transplanting the European Court of Justice: the experience of the Andean Tribunal of Justice". Oñati International Institute for the Sociology of Law. Social-Legal Series. 2011, vol 1, n ${ }^{\circ} 4$. 
conforme mencionado, o TJA é um dos tribunais supranacionais mais ativos, dentre os oito existentes no mundo ${ }^{12}$. A quantidade de decisões judiciais proferidas desde a sua criação é, realmente, impressionante, principalmente por se tratar de um tribunal comunitário sul-americano, região cujos Estados-Membros sempre tiveram que lidar com as dificuldades impostas ao seu projeto de integração e à incipiência de suas instituições, não apenas as regionais, mas também as internas.

As Interpretações Prejudiciais foram estabelecidas como mecanismo processual próprio do direito comunitário europeu. Estabelece a obrigatoriedade da consulta ao Tribunal de Justiça Europeu (TJE) quando o fundamento jurídico do pedido, na ação ajuizada perante juiz ou tribunal nacional, versar sobre normas comunitárias provindas de Regulamentos ou Diretivas. Para assegurar a interpretação e aplicação uniforme do direito comunitário em todo espaço de integração, tanto os juízes de primeira instância, facultativamente, como os Tribunais, em única ou última instância, neste caso, obrigatoriamente, devem remeter a questão ao Tribunal de Justiça Europeu, que é o único com competência para indicar a forma adequada de interpretação do direito colocado em questão. Esta interpretação é feita por sentença e, portanto, produz efeito vinculante aos tribunais nacionais. Da mesma forma, ocorre no TJA.

As consultas prejudiciais, ou seja, feitas antes do julgamento da ação, também estão previstas no MERCOSUL, onde são chamadas de Opiniões Consultivas, pois são exatamente isto: uma consulta, sempre facultativa, feita pelo juiz originário da causa ou por tribunal nacional, remetida ao Tribunal Permanente de Revisão do MERCOSUL (TPRM) quando houver qualquer dúvida sobre a aplicação de normas do direito de integração mercosulino. A decisão proferida pelo TPR, diferentemente do reenvio prejudicial europeu e andino, não vincula a interpretação que posteriormente será dada pelo juiz nacional quanto ao dispositivo em questão, embora pressuponha-se que, aquele que facultativamente consulta, esteja predisposto a atender o que foi estabelecido pelo tribunal consultado. Desde sua criação, até esta data, foram submetidas ao TPRM apenas três Opiniões Consultivas ${ }^{13}$.

Justamente em razão dos debates estabelecidos por ocasião do julgamento da Primeira Opinião Consultiva suscitada perante o Tribunal Permanente de Revisão do MERCOSUL, em 2007, o estudo das Interpretações Prejudiciais do Tribunal de Justiça Andino parecia promissor. Isto porque o voto do Relator Wilfrido Fernández de Brix e as divergências que foram levantadas pelos demais árbitros na decisão remetem a questões dogmáticas relativas à cooperação jurídica internacional vertical

12 ALTER, Karen et al. Op. cit.; HELFER, Laurence et al. Op. cit.

13 As três OP estão disponíveis em: <http://tprmercosur.org/pt/sol_contr_opiniones.htm> [acesso em 10.fev.2017]. 
estabelecida entre juízes nacionais e juízes comunitários, que, no caso do MERCOSUL, diferentemente da União Europeia e Comunidade Andina, não são qualificados propriamente como juízes, mas como árbitros, o que pode explicar os francos limites estabelecidos à sua atuação em relação ao Poder Judiciário dos Estados Membros.

$\mathrm{Na}$ OP $\mathrm{N}^{\circ}$ 01/2007 também são discutidos aspectos relativos à cooperação internacional horizontal, estabelecida entre os juízes nacionais dos Estados mercosulinos, cuja sistemática é regulada pelo Protocolo de Las Leñas ${ }^{14}$.

Os árbitros discutem os princípios comunitários que orientam a relação entre o direito comunitário e o direito nacional, e sobre a conveniência da consulta feita pelos juízes e tribunais nacionais ser obrigatória, como na CAN, ou facultativa, como no MERCOUSUL. Neste sentido, menciona decisões clássicas do Tribunal de Justiça da União Europeia ${ }^{15}$ e do Tribunal da Comunidade Andina ${ }^{16}$.

Os árbitros mercosulinos são unânimes ao consagrar o modelo do direito europeu, como o fez, sem exceções, o direito comunitário andino, e advogam pela conveniência do reenvio prejudicial obrigatório, independentemente da interpretação suscitada, objeto da decisão, já ter sido, inclusive, consolidada pelo Tribunal Comunitário, como ocorre no Tribunal de Justiça da Comunidade Andina, mas já superada, pela teoria do ato claro e esclarecido, pelo direito comunitário europeu ${ }^{17}$.

$\mathrm{O}$ não reconhecimento do ato claro ou esclarecido em acórdão precedente tem gerado, junto ao TJCA, um grande número de decisões de teor idêntico, sendo que, em uma amostragem cronológica, feita em $2009,90 \%$ delas referem-se às disputas relativas ao direito de marcas e patentes $^{18}$.

No processo originário, ajuizado perante uma instância nacional, no polo ativo encontra-se, quase que invariavelmente, uma empresa multinacional com sede em países europeus ou nos Estados Unidos. A Comunidade Andina tem adotado o modelo de integração comercial aberta, ao ampliar o livre-comércio aos tradicionais parceiros comerciais extracomunitários. No pólo passivo, como réus na disputa ou como parte interessada na decisão do órgão local, estão empresas locais ${ }^{19}$.

14 Protocolo de Cooperação e Assistência Jurisdicional em Matéria Civil, Comercial, Trabalhista e Administrativa. Decreto 6891, de 02 de julho de 2009.

15 TJCE, sentença de 15 de julho de 1964, Costa/ENEL e TJCA, sentença proferida no processo 1-IP-87 e 2-IP-90, que tratam da relação entre direito comunitário e direito interno, declarando a primazia do primeiro em relação ao segundo. Todas estas decisões estão disponíveis para consulta no sítio oficial da União Europeia e da Comunidade Andina.

16 Processo 03-IP-93. Outras decisões irão repetir as fórmulas consagradas nas decisões anteriores. Nesse aspecto, indica-se como referência atual o Processo 2-156-IP-2011.

$17 \mathrm{O}$ debate entre os árbitros do TPRM trata da teoria do ato claro e do ato esclarecido firmada pelo Tribunal de Justiça Europeu. A OP n. 07/2007 está disponível em: <http://tprmercosur. org/pt/docum/opin/OpinCon_01_2007_pt.pdf> [acesso em 10.fev.2017].

18 HELFER, Laurence R. Op. cit.

19 Sobre este aspecto material das decisões, Alter e Helfer mencionam: "The ATJ has been 
O teor e a quantidade dessas decisões evidenciam a inconsistência da exigência de se submeter ao Tribunal de Justiça Andino toda e qualquer matéria regulada pelo direito de integração da $\mathrm{CAN}$, não importando se o conteúdo da norma suscitada já tenha sido objeto de sentença interpretativa e seu sentido já se encontre definido ${ }^{20}$. Aliás, a decisão definitiva do caso cabe ao órgão jurisdicional local, que deve bem conhecer a determinação outras tantas vezes proferidas por seu tribunal comunitário ${ }^{21}$.

O levantamento das Interpretações Prejudiciais Andinas permitiu identificar as respostas para as primeiras questões levantadas: i) a origem das Interpretações Prejudiciais; ii) as matérias frequentemente suscitadas; iii) os sujeitos na relação jurídica subjacente ao processo ajuizado na instância nacional originariamente competente.

Quanto à procedência, invariavelmente, as Interpretações Prejudiciais provém de órgãos administrativos e não judiciais. São agências públicas com atribuição para o registro de marcas e patentes e instância com competência para a solução de controvérsias relativas ao direito à propriedade industrial.

Os sujeitos no procedimento são, hegemonicamente, empresas multinacionais que invocam seu direito à patente registrada ou ao uso de marca. Majoritariamente, grandes laboratórios farmacêuticos e fabricantes de produtos alimentícios que requerem o reconhecimento de direito de patente, para registro no país, ou então se insurgem contra empresa local, de mesma natureza, para impugnar patente registrada indevidamente ou para impedir a utilização de uma marca ou símbolo assemelhado aos adotados pela empresa requerente ${ }^{22}$.

given great preemptive forcees to Andean intellectual property rules than to other areas of Andean Law. The Tribunal has relied on the extensive and detail secondary legilslation on patests, trademarks, and copyrighs as an indication that the member states had 'sovereigny trasferred' their 'exclusive authority'over intellectual property issues to community level. See 1-IP-96: section III (holding that, in the area of intellectual property, member state cannot deviate from 'the common interests' of the community except by acting through Andean institutions'). ALTER et al., 2011, p. 22.

20 O Tribunal de Justiça Andino tem estatística atualizada sobre o número de IP julgadas desde 1987, quando a primeira foi proposta. Até o ano de 2015 tinham sido julgadas 3460 . Disponível em: <http://www.tribunalandino.org.ec/sitetjcal/index.php?option=com wrapper\&view=wrapper\&Itemid=24> [acesso em 10.fev.2017].

$21 \mathrm{O}$ relator da OP $\mathrm{N}^{\circ}$ 01/2007 argumenta que o sistema adotado pelo TJA é melhor e mais adequado "à realidade latino-americana" do que aquele definido pelo TJE, nos seguintes termos: "No nosso entender, o sistema vigente na Comunidade Andina é mais adequado, não apenas para nossa realidade do Mercosul, senão para a nossa realidade latino-americana em geral. Primeiro, porque a nossa realidade coadjuva melhor com a conscientização dos órgãos judiciais nacionais sobre a importância da interpretação prejudicial no marco do Direito Comunitário (ou Direito de Integração) e, segundo, porque com o risco de ser desnecessariamente repetitiva, proporciona ao Tribunal Comunitário a oportunidade de evolucionar e modificar seus próprios critérios anteriores. O direito é e deve ser sempre evolutivo".

22 Alguns exemplos: indústria farmacêutica Lilly (81-IP-2009), Kraft Foods Holding (104IP-2009); Hard Rock Café (78-IP-2009), The Prudential Insurence Company of America 
Por ocasião da pesquisa não foram tabulados os dados relativos à proporção entre empresas multinacionais solicitantes e empresa intrarregionais, nas demandas por marcas e patentes, e agora, a fidelidade desses dados ficou comprometida, posto que o TJA deixou de publicar, como fazia, a relação completa e cronológica das Interpretações Prejudiciais, identificadas pelo número de registro no Tribunal. Atualmente, permite apenas a consulta pelo número do procedimento.

Apesar da recorrência da matéria e da natureza das empresas autoras, hegemonicamente multinacionais, uma sentença merece destaque por colocar no pólo ativo a Organização Nacional Indígena na Colômbia (ONIC) que demanda contra a Superintendência da Indústria e Comércio da República da Colômbia, que concedeu a terceiro, Héctor Alfonso Bernal Sanchéz a concessão das marcas mistas (nome composto e logomarca) Coca Indígena e Coca Zagradha. Diferentemente da maioria das decisões proferidas, esta é suscitada pela Corte Constitucional da República da Colônia, ao invés das Juntas Arbitrais para Conflitos de Marcas e Patentes ${ }^{23}$.

Esta sentença, em especial, corresponde a todas as hipóteses suscitadas no início da investigação, e que se frustraram no seu desenvolvimento em razão da hegemonia do padrão "marcas/patentesempresa multinacional/empresa local".

Nela são encontradas as questões que traduzem especificidades regionais e o conteúdo alternativo às demandas comuns aos tribunais europeus. São suscitadas questões relativas à propriedade coletiva, a autonomia dos povos originários, a necessidade de consulta prévia às comunidades sobre o uso do seu patrimônio tradicional ${ }^{24}$.

Estes preceitos estão compreendidos no âmbito do princípio e função da subsidiariedade. Para o devido processo, a prioridade de decisão é da instância local, posto que a instância superior somente atua e intervém quando puder demonstrar que aquela não poderia fazê-lo de forma satisfatória. Neste sentido, a Organização Nacional Indígena argumenta que a Superintendência reconhece, na contestação apresentada à Corte Constitucional, o direito de autonomia e decisão das comunidades indígenas, o que é previsto pela Constituição ${ }^{25}$.

(61-IP-2009), Kellog (4-IP-2009), Pfizer Ireland Farmacêutica (70-IP-2009); Helena Rubinstein (72-IP-2009), Philips Morris Products S.A (80-IP-2009); Smith Kline Beechan Biological S.A (83-IP-2009), Nestlé Societé dês Produits S.A (79-IP-2009), Pharmabrands S.A e Soc. Merck and Co. (49-IP-2009), Laboratório Byly S.A (138-IP-2009), Sociedade Fujisawa Farmaceutical (139-IP-2009), Soc. Abbot (94-IP-2009), Alcon (141-IP-2009).

23 Disponível em: <http://www.tribunalandino.org.ec/sitetjca1/index.php?option=com _ filecabinet\&view $=$ files \&id=1\&Itemid=92> [acesso em 10.fev.2017].

24 Fundamenta o pedido na Constituição Política da Colômbia, na Convenção Americana de Direitos Humanos, no Convênio do Rio, ratificado pela Lei 165/94, no Convênio 169 da OIT, sobre Povos Indígenas e Tribais, ratificado pela Lei 21/91; a Lei 1037/2006, que aprovou a Convenção para Proteção do Patrimônio Cultural Imaterial (todas da Colômbia), e também Decisões Andinas 391 e 486.

25 Está suficientemente documentado que la hoja de Coca es tanto património biológico, 
Superada esta abordagem inicial, foram analisados o conteúdo das IP para averiguar: i) a contribuição das sentenças para a construção de um Direito Comunitário sul-americano, e ii) o papel dos tribunais comunitários na consolidação de um direito de integração regional com características próprias.

Em razão da primeira decisão do Tribunal Permanente de Revisão do MERCOSUL, que faz referências às sentenças do TJA, e também por sua profícua atuação, era esperado encontrar elementos que diferenciassem significativamente as instituições transplantadas pelos Estados sul-americanos, em relação às suas correspondentes nos Estados europeus.

Nãofoi possívelencontrar diferenças conceituaisou procedimentais que pudessem caracterizar um direito comunitário alternativo ao criado na Europa, mas a análise foi esclarecedora acerca do contexto, natureza e limites do projeto comunitário estabelecido na América do Sul, nesse caso, na Comunidade Andina, instituição objeto do estudo.

Se caracteres peculiares à região não levaram a especificidades significativas em relação às instituições europeias correspondentes, a prática consolidada das IP demonstrou que os sujeitos da relação jurídica subjacente podem ser diversificados, evidenciando as profundas diferenças socioeconômicas entre os dois blocos. Por ora, a forma como foi estabelecido o TJA e o teor de suas decisões evidenciam que sua atividade atende, principalmente, aos interesses de empresas multinacionais que na Comunidade Andina.

Quanto à contribuição para o aprofundamento da cooperação jurídica internacional, as Interpretações Prejudiciais analisadas não permitiram avaliar as relações entre os tribunais nacionais e comunitários e o enfrentamento de questões relativas ao direito de integração e a cooperação internacional vertical ou horizontal. São raras, por ora, as IP suscitadas pelos Tribunais propriamente ditos, como a Corte Constitucional da Colômbia na questão relativa ao patrimônio indígena. A maior parte das decisões provém de comissões arbitrais ${ }^{26}$.

O quadro encontrado evidencia que a integração aberta acordada entre a Comunidade Andina e Estados da União Europeia e Estados Unidos corrobora a tese de que o regionalismo sul-americano continua

como representa un valor cultural de sin igual importáncia de los pueblos indígenas, y en consecuencia se convierte en patrimonio recursos y sobre las innvoaciones que se hagan de los mismos. Pero entendemos que em función de la autonomia que el estado colombiano las reconoce, corresponde a ustedes definir quién y de qué manera usa ese património, pues mal puede nuestra entidad invadir competencias que no son suyas difiniendo una situación que la ley resolvió. cultural de la Nación, atendiendo principios constitucionales, en particular 7 y 8 de nuestra Carta Fundamental. Por otra parte el artíbulo 7 de la Decisión 391, Régimen Comum sobre Acceso a los Recursos Genéticos, reconece la facultad de decidir de manera autônoma el uso de tales.

26 No processo 156-IP-2011 é definida a consulta como obrigatória mesmo se tratando de árbitros do Tribunal de Arbitramento, pois estes são, no caso, os “juízes nacionais”. 
vinculado às relações comerciais históricas que perduram na região em longa duração. Esse parâmetro favorece interesses de empresas que se situam nos Estados centrais do sistema-mundo/colonial ${ }^{27}$.

\section{DIREITO COMUNITÁRIO E COLONIALIDADE: UMA HISTÓRIA DE LONGA DURAÇÃO}

Uma integração regional estabelecida segundo os paradigmas definidos pela União Europeia constitui um arranjo institucional que atende às necessidades de readequação de condições essenciais ao sistema-mundo: configuração de relações econômicas definidas por países centrais acordada com países periféricos em atenção a interesses comerciais de empresas situadas nos Estados que ocupam um posição hegemônica no sistema-mundo moderno ${ }^{28}$.

Neste sentido, para um projeto de integração alternativo ao estabelecido pela União Europeia não basta uma reconfiguração institucional e procedimental dos órgãos supranacionais andinos. É necessário que se materialize a aplicação dos princípios e objetivos estabelecidos nos tratados que precederam e inspiraram a formação dos blocos regionais sul-americanos.

A mudança institucional estaria longe de configurar, por si só, uma opção alternativa à funcionalidade clássica do sistema-mundo. $\mathrm{O}$ aprofundamento de relações socioeconômicas em detrimento de relações meramente comerciais, que, invariavelmente, atendem aos interesses do grande capital, não garantem a concretização dos princípios de solidariedade e cooperação comunitária com o objetivo de corrigir as assimetrias entre os Estados sul-americanos e o seu desenvolvimento equitativo. $\mathrm{O}$ principio da solidariedade, ou da função subsidiária dos organismos internacionais em relação aos seus Estados Membros está expresso em todos os tratados institutivos dos organismos regionais americanos, a começar pela Carta da OEA.

Um sistema de integração desenvolve-se de forma alternativa quando a prioridade do organismo regional está voltada à efetivação de políticas públicas voltadas às pessoas envolvidas no processo integracionista, seja na condição de trabalhador, de consumidor, de estudante interregional ou na condição daqueles que sofrem, direta ou indiretamente, os efeitos das intervenções comunitárias, como é o caso das populações afetadas pelas obras de infraestrutura física, energética e de comunicação realizadas, na região, em parcerias firmadas entre o

27 QUIJANO, Aníbal. Colonialidade do poder, eurocentrismo e América Latina. A colonialidade do saber: eurocentrismo e ciências sociais. Perspectivas Latino-Americana. Buenos Aires: Clacso, 2005, p. 117-142; e QUIJANO, Aníbal. Os fantasmas da América Latina. In NOVAES, Adauto (ed.). Oito visões da América Latina. São Paulo: Senac, 2006 , p. 49-85.

28 WALLERSTEIN, Immanuel. Op. cit.; e QUIJANO, Aníbal. Os fantasmas da América Latina. Ibíd. 
Banco Mundial e bancos de fomento, como o BNDS brasileiro, situados nos Estados Sul-Americanos. No âmbito da América do Sul, essas ações têm sido implantadas, principalmente, pela União das Nações Sulamericanas (UNASUL) por intermédio da Iniciativa para a Integração da Infraestrutura Regional Sulamericana (IIRSA) ${ }^{29}$.

$\mathrm{O}$ contexto no qual os Estados sul-americanos negociaram os recentes arranjos institucionais demonstra, entretanto, que os blocos de integração têm sido a melhor expressão do centralismo decisório e concentração institucional, elementos característicos e fundamentais à funcionalidade do sistema mundial de mercados, desde o século $\mathrm{XVI}^{30}$.

Os acordos firmados na década de 1990, sob influência das negociações desenvolvidas durante a Rodada do Uruguai, do GATT, e da instituição da OMC, determinaram a reestruturação institucional dos organismos de integração existentes na América do Sul, como o Pacto Andino, conferindo-lhes a forma atualmente vigente. Neste período foi instituído o Sistema de Integração Andino (SAI), integralmente transplantado da União Europeia, e o MERCOSUL, que, embora tenha adotado uma arquitetura diferente, foi igualmente inspirado no modelo de mercado comum inspirado nos paradigmas clássicos do livre-mercado.

Essas reformas foram também impulsionadas pelos Planos de Ajuste Estrutural (PAE) firmados no mesmo período entre Estados sul-americanos eoFundoMonetário Internacional(FMI), em parceriacomoBancoMundial, visando a implantação, na região, dos preceitos fixados pelo denominado Consenso de Washigton. A execução das metas estabelecidas pelos PAE garantiria, aos governos locais, acesso a empréstimos disponibilizados pelo Banco Mundial e por instituições financeiras privadas para obras de infraestrutura, além da assessoria de técnicos para a elaboração de projetos voltados às reformas institucionais exigidas.

Nos anos 90 foram ratificados os protocolos adicionais ao Acordo de Integração Subregional Andino, conhecido como Acordo de Cartagena, negociado no âmbito da Associação Latino-Americana de Livre Comércio (ALALC) que instituiu o Pacto Andino, vigente desde 26 de maio de 1969.

Naquele momento, o Pacto Andino recepcionara o ideário consagrado pelos desenvolvimentistas cepalinos, economistas sulamericanos, que o desenvolveram em fóruns regionais realizados a partir da década de 1950 sob a tutela e patrocínio das Nações Unidas. A CEPAL, Comissão Econômica para a América Latina, com sede em Santiago do Chile, tinha como objetivo a formulação e planejamento de políticas públicas a serem desenvolvidas por Estados da região. Segundo esses acadêmicos, a promoção do desenvolvimento econômico e social é

29 Para maiores informações sobre o programa consultar sua página oficial na internet. Disponível em: <http://www.iirsa.org/> [acesso em 12.fev.2017].

30 WALLERSTEIN, Immanuel. Op. cit. 
responsabilidade dos governos, cujas instituições são as únicas capazes de substituir a ação popular em Estados subdesenvolvidos, em razão de possuírem reduzido capital social. Raúl Prebisch, argentino, e Celso Furtado, brasileiro, são expoentes deste grupo ${ }^{31}$.

Dos organismos de integração criados na América do Sul, o Pacto Andino foi o que mais avançou no seu processo de institucionalização. Progrediu, embora timidamente, durante parte das décadas de 1970 e 1980 e permaneceu praticamente inalterado até 1996, quando ocorreram mudanças significativas em sua estrutura institucional. Da mesma forma que ocorrera na década de 1960, a reforma dos anos 90 foi promovida segundo o que era preceituado e viabilizado pelas organizações internacionais globais, antes, a CEPAL, órgão do Conselho Econômico e Social das Nações Unidas, recentemente, o FMI, Banco Mundial e OMC.

Com a vigência do Protocolo Modificatorio del Acuerdo de Integración Subregional Andino, aprovado em Trujillo, Peru, em 10 de março de $1996^{32}$, conhecido como Protocolo de Trujillo, foi instituído o Sistema Andino de Integração e o bloco econômico adotou o nome Comunidade Andina. À estrutura institucional já estabelecida, juntou-se o Conselho Presidencial Andino, equivalente ao Conselho Europeu, e o Conselho Andino de Ministros de Relações Exteriores, que corresponde ao Conselho da União Europeia. Ambos têm competência normativa, antes concentrada na Comissão da Comunidade Andina. A Junta, criada pelo Acordo de Cartagena, órgão técnico do Pacto Andino, tornou-se o Secretariado-Geral da Comunidade Andina, com funções administrativas e jurisdicionais.

Em 2001, o Conselho Andino de Ministros de Relações Exteriores editou a Decisão 500, que regulamentou o funcionamento do Tribunal de Justiça Andino e estabeleceu o procedimento das diversas ações relativas ao processo judicial comunitário, todas inspiradas no processo comunitário europeu. A Decisão modificou o Tratado de Criação do Tribunal de Justiça, de 1984, já inspirado no Tribunal de Justiça Europeu, adaptando-o aos termos do Protocolo de Trujillo.

Este transplante institucional desconsiderou que, com o passar do tempo, o próprio Tribunal de Justiça Europeu demonstrou não ser, absolutamente, essencial ao projeto de integração, que depende, muito mais, de ações administrativas concretas e, portanto, de políticas públicas implantadas pelos governos de cada Estado Membro.

Nos Preâmbulos de todos esses tratados são relacionados princípios e objetivos que traduzem o percurso histórico peculiar e as características

31 COLISTETE, Renato Perim. "O desenvolvimentismo cepalino: problemas teóricos e desenvolvimento no Brasil”. Revista do Instituto de Estudos Avançados. 2001, vol 15, no 41.

$32 \mathrm{O}$ documento pode ser encontrado em: <http://www.comunidadandina.org/Normativa. aspx\#> [acesso em 15.fev.2017]. 
sociais, culturais e políticas específicas que distanciam os Estados sulamericanos dos europeus. De qualquer forma, os dois blocos continuam intimamente conectados, como evidencia o sistema jurídico comunitário. A análise de suas normas e decisões judiciais permite dimensionar o quanto o substrato econômico que integra os dois continentes desde o século XV continua, até o século XXI, solidamente estruturado.

O MERCOSUL, que resulta do mesmo contexto em que foram restabelecidas as instituições comunitárias da América Andina e da América Central, refundadas sob os preceitos do Consenso de Washington e das diretrizes firmadas na Rodada do Uruguai, diferenciase, entretanto, em vários aspectos, dos organismos de integração que o antecederam, a Organização dos Estados Centro Americanos (ODECA) e o Pacto Andino.

O Protocolo de Ouro Preto, que regulamentou o Tratado de Assunção ao estabelecer a estrutura institucional do MERCOSUL, prescreve, em seus dispositivos, ao menos no que se refere à supranacionalidade das instituições comunitárias e à forma de internalização de suas normativas, um procedimento diverso daquele adotado, desde suas origens, pelas Comunidades Europeias, pela Comunidade Andina e pelo Sistema de Integração Centro-Americano (SICA), antiga ODECA.

No MERCOSUL, o princípio da subsidiariedade, embora não declarado, prevalece sobre o princípio da supranacionalidade das instituições comunitárias. Esta característica é mais adequada aos Estados sul-americanos, que expressamente consagram, de forma contundente, em cada uma de suas Constituições políticas, os princípios da soberania, da autodeterminação, da não intervenção e independência, que, na região, possuem um conteúdo jurídico especial em face ao seu passado colonial.

A necessidade de se estabelecer, na América, um modelo de integração regional diferente do europeu envolve desde aspectos físicos elementares, tal como a falta de infraestrutura de transportes e de comunicação entre os Estados Sul-Americanos, quanto aspectos de ordem histórica, como os graves problemas socioeconômicos de seus países, que vão da extrema vulnerabilidade econômica e pobreza de suas populações à insuficiência de desenvolvimento capitalista. Uma realidade, portanto, bastante diferente daquela da Europa, mesmo depois de sua destruição pelas duas guerras mundiais sucessivas, fator que justificou a criação das estruturas supranacionais e do mercado comum entre os Estados que sofreram os efeitos daquelas disputas coloniais.

Nas duas ocasiões, em 1950 e em 1990, o sistema-mundo seria reorganizado, pois os tradicionais Estados hegemônicos perceberam o risco de serem superados por novas hegemonias globais. Nesses 
momentos críticos do capitalismo, revitalizam-se os projetos de integração entre Estados sul-americanos, que passam a ser estimulados pelos organismos econômicos de caráter mundial em resposta à funcionalidade sistêmica do mercado internacional.

\section{PRINCÍPIOS COMUNITÁRIOS EUROPEUS E JURISPRUDÊNCIA ANDINA}

Quando foi firmado em 1969, o Pacto Andino não previa um Tribunal Internacional. No entanto, a partir de meados de 1970, a alegada dificuldade de efetivação do direito comunitário derivado pelos Estados-Membros, ou seja, das Diretivas emanadas da Comissão Andina, acabou levando à sua instituição.

Naquele momento, as Decisões da Comissão Andina eram incorporadas ao ordenamento jurídico interno da cada Estado mediante Decreto Presidencial. No entanto, setores empresariais da Colômbia argüiram, perante sua Suprema Corte, que normas de conteúdo macroeconômico não teriam validade interna sem o controle prévio dos parlamentos nacionais, e estes argumentos foram acolhidos pelo tribunal ${ }^{33}$.

Com essa decisão da Corte Constitucional colombiana, uma lei nacional, norma interna, decisão unilateral do Estado, poderia revogar ou ter primazia em relação ao Direito Comunitário vigente, decisão normativa de todos os Estados Membros, o que praticamente tornaria suas normativas inócuas, mesmo quando versassem sobre matéria de competência exclusiva da Comissão Andina. Como efeito da jurisprudência firmada pela Suprema Corte, todo sistema de integração restaria desacreditado.

Em face dessas circunstâncias, a Comissão passou a defender a criação de um Tribunal Comunitário para garantir o cumprimento do direito regional junto aos Estados-Membros. Essa ponderação provocou a consulta ao Instituto para a Integração da América Latina $e$ Caribe (INTAL), órgão consultivo do Banco Interamericano para o Desenvolvimento (BID), para que emitisse um parecer sobre o melhor modelo de tribunal para a região.

Sobre este episódio, Karen Alter, Laurence Helfer e Osvaldo

\footnotetext{
33 Alter, Helfer e Saldías também mencionam processo ajuizado perante a Corte Constitucional da Colômbia no qual o autor requer que seja declarada a inaplicabilidade de normativas colombianas relativas à produção e comércio do álcool por serem contrárias ao direito comunitário. A Corte negou o pedido do autor sob o argumento de que apenas as normas relativas aos direitos humanos teriam hierarquia superior às leis, o que não é o caso das normativas comerciais comunitárias, que seriam equivalentes e não superiores às normas internas. Os autores comentam: "The Colombian Court adopted somewhat abstruse reasoning, stating that community Law has 'primacy' over conflicting national law, but suggesting that primacy means that community law 'displaces but does not abrogate o render non-executable' confliticting national legislation'”. ALTER, Karen et al. Op. cit., p. 22.
} 
Saldías comentam:

INTAL is a research Center established by the Inter-American Development Bank in 1965 with mission of promoting and consolidating regional integration. Its networks of consultants - many of whom are part-time scholars - provides technical assistance to implement and enforce integration policies. INTAL served as a conveyer belt for the transmission of European ideas into conversations about integration in Latin America. At the time, many INTAL consultants had been educated and trained in European universities, and they continued to attend pro-integration events in Europe.(...) In June 1972, the Junta convened a Meeting of Experts that included INTAL consultants, Professor Gerald Olivier (the Assistant Director of EC Legal Services), and ECJ Judge Pierre Pascatore. Based on this meeting, the Junta prepared a draft of a treaty establishing the ATJ. Representatives of the member states discussed the draft in November 1972, and December a joint Junta-INTAL working group presented its proposals to the Commission. The proposal focused on two key requirements: the doctrines of supremacy and direct effect, and a supranational mechanism to review the legality of community acts. (...) It created an Andean judicial body to review the correct interpretation os Andean rules by national judges $^{34}$.

Apesar da decisão intergovernamental de se instituir uma Corte Comunitária ter sido proferida em 1972, o Tribunal somente iniciou seus trabalhos em 1984.

Posteriormente, com o Protocolo de Cochabamba, de 1996, o Tribunal foi reestruturado, conformando-se, definitivamente, com o modelo europeu. O Protocolo de Cochabamba foi regulamentado pela Decisão $n^{\circ} 500$ do Conselho da Comunidade Andina, que instituiu o Estatuto do Tribunal de Justiça da Comunidade Andina, estabelecendo os princípios, fontes e forma de aplicação do direito comunitário, além de seus ritos processuais.

O órgão judiciário supranacional sul-americano transplantou para a região andina princípios e procedimentos que levaram tempo para ser concebidos e consolidados pela jurisprudência e pela doutrina europeia. Seu surgimento tardio, em relação ao europeu, levou à recepção desses institutos nos tratados da Comunidade Andina sem o amadurecimento paulatino que caracterizou as instituições jurídicas das Comunidades Europeias. A jurisprudência do TJA passou, assim, a reproduzir os princípios do Direito Comunitário sem atentar para as peculiaridades políticas e econômicas desta sub-região americana.

O Protocolo de Cochabamba e a Decisão 500 do Conselho Andino, que o regulamenta, reconhecem as duas fontes típicas do direito

$\overline{34 \text { ALTER, Karen. }}$ et al. Op. cit. p. 12. 
comunitário: os tratados institutivos e seus protocolos, normas primárias negociadas e firmadas em conferências de cúpula e incorporadas segundo disposições constitucionais de cada Estado, e as Decisões, lato senso, normas secundárias ou derivadas emitidas pelos órgãos comunitários aos quais os tratados atribuem competência normativa, que a exercem segundo os princípios e limites igualmente estabelecidos pelo tratado institucional.

Nesse sentido, as Comunidades Europeias desenvolveram, de fato, um novo mecanismo de elaboração de normas internacionais e de sua incorporação ao ordenamento jurídico dos Estados, inaugurando o sistema do efeito direto e imediato de normativas internacionais, que não necessitam da manifestação de qualquer órgão nacional para aperfeiçoar sua vigência interna.

Até então, apenas os procedimentos de elaboração e internalização dos tratados internacionais tinham sido objeto de estudos e de consolidação normativa, tanto internacional como nacional. O regime de elaboração e de internalização dos tratados são regidos pela Convenção de Viena sobre Direito dos Tratados e, no âmbito dos Estados, por suas Constituições políticas.

Até o surgimento das Comunidades Europeias não se conhecia o efeito direto e imediato, junto ao ordenamento jurídico de cada Estado, de normas internacionais. A novidade foi instituída em razão das normativas derivadas dosorganismos comunitários. São os regulamentos, diretivas, decisões, resoluções comunitárias que, uma vez reconhecidas como superiores às leis, suscitaram debates acerca da relativização da soberania estatal pela ingerência de órgãos supranacionais em assuntos, até então, estritamente internos aos Estados.

Todas as Constituições dos Estados da América do Sul estabelecem os procedimentos de incorporação dos tratados ao ordenamento jurídico interno, e a forma de internalização, em todos eles, é, em grande medida, parecida, pois exige a prévia autorização dos Parlamentos locais como condição para posterior ratificação presidencial e vigência internacional e interna do tratado.

Quanto às normas derivadas dos órgãos comunitários, a forma e o momento de sua vigência junto aos Estados-Membros do organismo de integração regional são previstos pelo tratado constitutivo, que, neste sentido, inovou e se antecipou às previsões constitucionais sobre tal procedimento, tanto na Europa como na América.

Posteriormente, os Estados da União Europeia e da Comunidade Andina reformaram suas Constituições de forma a incorporarem, em seu texto, a denominada cláusulas de abertura ao direito comunitário para o reconhecimento do seu efeito direto e imediato junto às instituições nacionais.

O princípio da primazia do direito comunitário foi recepcionado 
textualmente pelo direito de integração andino. Como conseqüência, a lei nacional apenas prevalece quando ainda não houver disposição comunitária aplicável à questão. Enfim, nesse caso, a função da norma interna é integradora, ela preenche uma lacuna do direito comunitário. $\mathrm{Na}$ Comunidade Andina esse entendimento é possível mesmo quando a matéria for de competência exclusiva dos órgãos de integração: em face da ausência normativa, aplica-se a lei nacional, se esta for compatível com os objetivos e princípios da integração regional.

O princípio da aplicação direta do direito comunitário derivado pelojuiz nacional também foiincorporado pelos tratados ejurisprudência andina. Assim, tão logo vigente, nos termos do tratado constitutivo, o direito de integração poderá ser suscitado perante os tribunais internos. Nesse caso, o juiz, diante de uma possível incompatibilidade entre a norma comunitária e a nacional, sempre aplicará a primeira em detrimento da segunda.

Uma vez recepcionados tais princípios do direito comunitário europeu, a Decisão 500 da Comunidade Andina determina que toda norma comunitária andina suscitada perante tribunais internos, para ser aplicada, deve ser previamente interpretada pelo tribunal comunitário. A providência visa, conforme o direito europeu e andino, criar um entendimento uniforme do direito comunitário pelos juízes e tribunais dos diferentes Estados-Membros.

A consulta do juiz ao TJA será facultativa quando o processo ainda estiver sujeito a recurso, mas será sempre obrigatória quando estiver em último grau de jurisdição ou quando o caso for de competência originária dos órgãos jurisdicionais superiores. Na consulta obrigatória o processo original é suspenso. Daí no nome do incidente: Interpretação Prejudicial, isto é, feita necessariamente antes do julgamento definitivo da ação originária aviada perante o juiz nacional ${ }^{35}$.

35 Decisão 500 Conselho Andino. Artículo 121. Objeto y finalidad. Corresponde al Tribunal interpretar las normas que conforman el ordenamiento jurídico de la Comunidad Andina, con el fin de asegurar su aplicación uniforme en el territorio de los Países Miembros. Artículo 122. Consulta facultativa. Los jueces nacionales que conozcan de un proceso en el que deba aplicarse o se controvierta alguna de las normas que conforman el ordenamiento jurídico de la Comunidad Andina, podrán solicitar, directamente y mediante simple oficio, la interpretación del Tribunal acerca de dichas normas, siempre que la sentencia sea susceptible de recursos en derecho interno. Si llegare la oportunidad de dictar sentencia sin que hubiere recibido la interpretación del Tribunal, el juez deberá decidir el proceso. Artículo 123.Consulta obligatoria De oficio o a petición de parte, el juez nacional que conozca de un proceso en el cual la sentencia fuera de única o última instancia, que no fuere susceptible de recursos en derecho interno, en el que deba aplicarse o se controvierta alguna de las normas que conforman el ordenamiento jurídico de la Comunidad Andina, deberá suspender el procedimiento y solicitar directamente y mediante simple oficio, la interpretación del Tribunal. 


\section{INTERPRETACÕES PREJUDICIAIS E O PRINCÍPIO DA SUBSIDIARIEDADEE}

Se desde meados da década de 1960 até 1990 parecia haver convicção acerca da necessidade dos tribunais supranacionais, atualmente, este entendimento encontra-se abalado. O desenvolvimento das Comunidades Europeias e do próprio direito europeu, na sua primeira década de existência, prescindiram da atuação do Tribunal de Justiça Europeu. No entanto, acreditava-se que sua atuação seria essencial para que o direito comunitário fosse respeitado pelos Estados e para que, uma vez aplicado pelo juiz nacional, sua interpretação fosse uniforme em todos os Estados que compunham as Comunidades Europeias ${ }^{36}$.

Para garantir seu cumprimento pelos Estados, as normas processuais comunitárias prevêem a Ação de Incumprimento e, para assegurar a uniformidade de sua aplicação, as Interpretações Prejudiciais, que, como dito, são incidentes processuais provocados pelas partes ou pelo juiz de primeiro grau, quando normativas do direito comunitário fundamentam o pedido original. Quando a ação estiver em último grau de recurso nos Tribunais superiores, ou a matéria for de sua competência originária, o reenvio será obrigatório. $\mathrm{O}$ processo ficará suspenso até a manifestação do Tribunal comunitário, que, por sentença vinculante, orientará o juiz da causa sobre a melhor interpretação e melhor forma de aplicação das normativas em questão.

De início, entendia-se que qualquer pedido fundamentado no direito comunitário suscitado perante uma Corte nacional obrigaria o reenvio da questão ao TJE. Este, sem entrar no mérito do litígio, deveria proferir a interpretação e sugerir a aplicação mais adequada para a normativa suscitada. No entanto, em razão do volume de questões que passaram a ser levadas ao TJE e, principalmente, em razão da repetição freuente das matérias, a Corte Europeia, no paradigmático caso CILFIT, de $1982^{37}$ firmou o entendimento de que quando o dispositivo comunitário for suficientemente claro, ou no caso da questão já ter sido objeto de decisão anterior e já estivesse, portanto, suficientemente esclarecida, os tribunais nacionais não estariam obrigados a promover o incidente de Interpretação Prejudicial, evitando, assim, o retardamento da decisão definitiva, em prejuízo da administração da Justiça. Essa nova disposição, trazida pela jurisprudência comunitária, ficou conhecida como "teoria do ato claro" e "teoria do ato esclarecido", respectivamente.

O debate acerca da obrigação ou faculdade do juiz local em submeter a questão ao Tribunal Comunitário foi um dos pontos discutidos por ocasião da decisão proferida na primeira Opinião Consultiva (OP No 1/2007) submetida ao Tribunal Permanente de

36 ALTER, Karen et al. Op. cit., p.3.

37 Disponível em: <http://eurlex.europa.eu/LexUriServ/LexUriServ.do?uri=CELEX:61981CJ0283:EN:HTML> [acesso em 12.fev.2017]. 
Revisão do MERCOSUL. Nela, os árbitros fazem referência às sentenças proferidas pelo TJA, que, invariavelmente, tratam da questão em todas as IP aviadas.

Os árbitros mercosulinos, naquele momento, insurgiram-se contra o fato do MERCOSUL ter optado por uma sistemática diferente daquela adotada pela União Europeia e pela Comunidade Andina. Segundo o Protocolo de Olivos, no procedimento da Opinião Consultiva, como o próprio nome do instituto indica, o juiz nacional não esta obrigado a submeter a norma mercosulina suscitada à interpretação do TPRM. Se, por sua vez, reenvia a questão ao Tribunal do MERCOSUL, a decisão arbitral proferida é insuscetível de vincular o juiz que a suscita ${ }^{38}$, portanto, não se trata de uma sentença e seus termos não são obrigatórios. Como conseqüência, apenas três OP foram reenviadas ao TPRM desde sua criação, em agosto de 2004.

A situação é muito diferente do TJA, que, desde sua criação, em 1979, até 2015, julgou 3460 IP $^{39}$. No entanto, a análise das Interpretações Prejudiciais proferidas pelo TJA ao longo de sua existência evidencia que o procedimento de reenvio ao tribunal comunitário deveria, ao menos, recepcionar, como a UE, de onde importa o procedimento, o princípio do ato claro e do ato esclarecido, evitando a profusão de decisões praticamente idênticas como as que têm sido proferidas pela Corte Andina.

A subsidiariedade, no direito comunitário determina que a interveniência dos órgãos supranacionais seja feita apenas nos casos em que as instituições locais ou nacionais não possam fazê-lo de forma mais adequada e eficaz. Ora, os juízes e tribunais nacionais devem ser presumidamente aptos à compreensão e aplicação do direito de integração sem que seja necessária e obrigatória a suspensão do feito original para a manifestação dos juízes comunitários.

Neste aspecto, o MERCOSUL, com a criação do Fórum de Cortes Supremas, em novembro de 2004, parece ter encontrado uma solução mais adequada para a região e mais eficaz para as partes envolvidas em um processo judicial. Nos seus encontros tem debatido formas de cooperação jurídica entre os Estados e mecanismos de harmonização do entendimento entre os tribunais dos Estados Membros, além do cumprimento e aplicação do novíssimo direito de integração regional.

Mais uma vez, o MERCOSUL opta por acatar integralmente o

38 O Relator da OC $n^{\circ}$ 1/2007, Dr. Wilfrido Brix justifica, em seu voto, sua opinião a este respeito, combatendo a mera faculdade do juiz. Afirma, inclusive, que prefere o sistema da CAN, que não recepcionou a tese do ato claro e esclarecido. Disponível em: <http://www. mercosur.int/innovaportal/file/PrimeraOpinionConsultiva-Versionfinal.pdf?contentid=377 \&version $=1 \&$ filename $=$ PrimeraOpinionConsultiva-Versionfinal.pdf $>$ [acesso em 17.fev.2017]. 39 Dados estatísticos relacionados à IP estão disponíveis em: <http://www.tribunalandino.org.ec/ sitetjcal/index.php?option=com_wrapper\&view=wrapper\&Itemid $=24>$

[acesso em 12.fev.2017]. 
princípio da subsidiariedade em todos os seus aspectos, mesmo que este não tenha sido expresso pelos tratados mercosulinos. A Comunidade de Estados, organismo supranacional por natureza, deve ser capaz, em sua atuação, de criar mecanismos alternativos para estimular e consolidar a integração das diversas instituições estatais envolvidas no projeto de regionalização, inclusive o Poder Judiciário. O Fórum das Cortes Supremas é um exemplo. Quando instituições nacionais cooperam entre si, de forma adequada à demanda regional e de maneira eficiente aos diretamente interessados, a cooperação vertical, isto é, a que se realiza entre os Estados Membros e a Comunidade, poderá ser aprofundada e aperfeiçoada instituindo um ambiente de verdadeira integração institucional.

\section{OS SUJEITOS INTERESSADOS NAS INTERPRETAÇÕES PREJUDICIAIS DA COMUNIDADE ANDINA}

Apesar da obrigação do tribunal nacional de submeter ao Tribunal de Justiça Andino a interpretação da norma comunitária suscitada na ação original, dentre 283 decisões consultadas aleatoriamente não foi possível encontrar qualquer uma que tenha sido suscitada por órgão judiciário local. Todos os processos demandado com base no direito comunitário foram suscitados perante órgãos administrativos, competentes para matéria especialmente relacionada ao direito de marcas e patentes ${ }^{40}$.

Um dos aspectos a ser levado em consideração para explicar o fato é a competência exclusiva do Conselho Andino, principal órgão normativo da CAN, para regular toda matéria relativa à propriedade intelectual, e somente as normas de competência exclusiva do Conselho tem primazia em relação as do direito interno por entendimento firmado pelas Cortes Constitucionais dos Estados Membros.

Sobre este aspecto, é necessário pontuar que leis internas e normativas andinas anteriores ao Protocolo de Trujillo não reconheciam o direito à propriedade industrial e intelectual, com fundamento no direito ao desenvolvimento científico e tecnológico preconizado pela política econômica cepalina.

A política econômica preconizada pela CEPAL para o desenvolvimento capitalista na América Latina incluía o controle do capital estrangeiro, a nacionalização da economia, isto é, o fortalecimento das empresas de capital nacional e o estímulo às estrangeiras para se nacionalizarem formando, com companhias locais, sociedades de capital misto, o protecionismo tributário, como política parafiscal

40 As IP suscitadas pelas Supremas Cortes dos Estados-Membros são recentes. Identificamos apenas a IP 60-IP-2012 - Protección de la propiedad industrial y respeto al patrimonio biológico. 
de substituição de importações e estímulo à indústria nacional, e, inclusive, o não reconhecimento de patentes consideradas essenciais ao desenvolvimento científico e tecnológico regional ${ }^{41}$.

A partir de 1991, toda a regulamentação de inspiração cepalina foi revogada por determinação dos Planos de Ajuste Econômico firmados entre os Estados andinos e o Fundo Monetário Internacional. Naquele momento, também ocorriam as negociações da Rodada do Uruguai do GATT, que culminaram com a criação da OMC, em 1995. Foi neste novo contexto econômico que surgiram as Decisões comunitárias que impuseram significativa flexibilização das normas nacionais até então vigentes nos Estados andinos e que determinaram a criação de Agências Nacionais para Registro de Patentes ${ }^{42}$, os órgãos de onde provêm todas as IP que analisamos ${ }^{43}$.

Outro aspecto a ser levado em consideração, para explicar a ausência de questionamentos judiciais junto ao TJA, pode estar relacionado à resistência dos juízes e tribunais nacionais em considerar as normas comunitárias, em matéria de competência concorrente, como supranacionais, conferindolhes primazia em relação ao direito interno ordinário.

Embora as Constituições na América do Sul sejam todas monistas, ou seja, reconhecem os tratados internacionais como parte de seu ordenamento jurídico e definem, hierarquicamente, sua relação com normas constitucionais e infraconstitucionais, a recepção do direito comunitário exige disposição especial por se tratarem de normas secundárias, ou seja, emanadas de órgãos aos quais os tratados ratificados conferem competências normativas. Todo o instrumental teórico e jurisprudencial do direito comunitário decorre das normas de integração de caráter secundário, ou originadas de fontes derivadas de tratados internacionais. No entanto, o acórdão paradigmático da

$\overline{41 \text { Decisión 24/1970 }}$ da Comisión Andina sobre Régimen común de tratamiento a los capitales extranjeros y sobre marcas, patentes, licencias y regalías; Decisión 85/74 sobre Propiedad Industrial (ver especialmente os seus arts. $4^{\circ}$ e $5^{\circ}$ ). Após 1991 são editadas Decisões que flexibilizam o rigor das primeiras: Decisión 291/1991 e Decisión. 311/199, que revogán la Decisión 24/70 e Decisión. 85/74, seguidas pela a Decisión 344/1994, que estabelece o Regime Común sobre Propiedad Industrial, detalhado pelas Decisões n. 486/2000, 632/2005 e $689 / 2008$. Todas estas normativas estão disponíveis no sítio oficial da Comunidade Andina: <http://www.comunidadandina.org/Normativa.aspx\#> [acesso em 30.jul.2013].

42 HELFER, Laurence et al. Op. cit.; e PEREZ, Cecília Falcone. "Ecuador: new intellectual property Law". Grain, oct.28.1998. Disponível em:<http://www.grain.org/article/entries/1915ecuador-new-intellectual-property-law. Acesso em 30> [acesso em 17.fev.2017].

43 O Peru instituiu, em 1992, o Instituto Nacional de Defensia de La Competencia y de La Protección de la Propiedad Industrial (INDECOP), que conta com um Tribunal com competência para litígios envolvendo direito de concorrência, propriedade industrial e proteção do consumidor; no mesmo ano de 1992, a Colômbia instituiu a Superintendência de Industria e Comércio (SIC). Em 1996, a Bolívia criou o Servicio Nacional de Propiedad Intelectual; em 1997, a Venezuela criou o Serviço Autônomo de Propriedade Intelectual (SAPI); em 1998, o Equador instituiu o Instituto Equatoriano de Propriedade Intelelectual (EIIP). PEREZ, Cecília Falcone. Op. cit. 
Corte Constitucional da Colômbia ${ }^{44}$ contribuiu para uniformizar o entendimento, entre os tribunais dos outros Estrados, de que tanto tratados como as Decisões e Resoluções andinas são equivalentes às leis nacionais, o que significa que são passíveis de serem revogadas por elas, quando se tratar de matéria de competência concorrente a CAN e Estados Membros.

Esta construção jurisprudencial é outra peculiaridade do direito andino em relação ao direito europeu, que merece ser destacada. O direito comunitário europeu, neste aspecto, revolucionou as estruturas do direito internacional clássico justamente por conferir supranacionalidade a espécies normativas até então estranhas, pelo menos raras, no direito internacional, as Resoluções dos órgãos internacionais. São desta espécie os Regulamentos e as Diretivas Europeias, que tem primazia em relação ao direito interno dos Estados comunitários. Assim também as Decisões e Resoluções Andinas. No entanto, suas condicionantes históricas foram registradas em suas Constituições que consagraram princípios estranhos às suas correspondentes em Estados europeus, como o da não intervenção, independência, autoderminação, soberania: termos consagrados em cada uma das Constituições da América.

Este entendimento confere, na prática jurídica, a prioridade ao direito nacional em relação ao comunitário, e não o contrário, como determina tanto o Acordo de Cartagena como o Tratado de Criação do Tribunal de Justiça da CAN, denominado Protocolo de Cochabamba, e é indicativo da resistência dos juízes nacionais a um sistema regional ou internacional. Apesar do monismo constitucional, a tradição dualista esta arraigada nas instituições nacionais dos Estados sul-americanos, e só tem sido superada recentemente, quando as Constituições dos Estados passaram a tratar, em seu texto, da questão com mais clareza. Neste aspecto, o Brasil encontra-se alguns passos atrás dos demais Estados sul-americanos. Essa tradição sul-americana, a refletir sua história colonial, indica a pertinência do princípio da subsidiariedade na relação entre organismos de integração e Estados nacionais.

Helfer, ao se referir a ausência de provocações judiciais junto ao Tribunal Andino, aponta uma outra questão a ser considerada: a própria debilidade e falta de estrutura dos sistemas judiciários nacionais como fator inibidor da cooperação vertical. A falta de tradição e capacitação do Poder Judiciário local evidenciaria, não sua resistência, mas sua incapacidade de responder, adequadamente, às questões decorrentes da integração comercial ${ }^{45}$.

44 Neste sentido a sentença proferida apela Corte Constitucional da Colômbia, Sentença c-256/98 de 27 de maio de 1998, Seção 3.1.

45 Este aspecto também é levado em consideração pelo Professor Laurence Helfer, da Duke University e pela Professora Karen Alter, da Northwestern University, ambas nos Estados Unidos. Dentre as questões que seus trabalhos procuram responder destacamos: "Why have Andeans judges and officials been able to induce widespread respect for Andean rules 
O fato é que a regulamentação de toda matéria relativa à concorrência, propriedade industrial e direito de marca é de competência exclusiva do Conselho da Comunidade Andina e, no âmbito local, aplicada pelas agências reguladoras criadas junto aos Estados-Membros.

Quanto aos sujeitos nas relações jurídicas originárias estes são, quase que invariavelmente, empresas multinacionais com sede, principalmente, em países europeus, e empresas locais, circunstância que indica a condição periférica comum a todos os Estados sul-americanos, o que demonstra a permanência do seu lugar no sistema-mundo moderno, expressão cunhada por Immanuel Wallerstein e, posteriormente, adaptada por Aníbal Quijano para sistema-mundo/colonial, que melhor expressa as relações desiguais no capitalismo (QUIJANO, 2006).

A presença de empresas extrabloco como partes interessadas nesses processos comunitários, deve-se à reforma no Acordo de Cartagena, em 1996, que instituiu uma zona de integração aberta, revogando os preceitos protetivos originais do Pacto Andino. Logo na primeira alínea do seu art. $3^{\circ}$ ficou estabelecido, como objetivo fundamental da CAN, a "profundización de la integración con los demás bloques económicos regionales $y$ de relacionamiento con esquemas extrarregionales en los ámbitos político, social y económico-comercial”. Este mecanismo permite à Comunidade Andina realizar acordos que ampliam a zona de livrecomércio para Estados ou organizações comunitárias estranhas à Associação Latino Americana de Integração (ALADI), o que consolida os tradicionais fluxos comerciais que ligam a região a Europa e aos Estados Unidos, em detrimento de seus parceiros andinos ou mercosulinos.

Essa opção foi determinada em razão da forte ingerência dos Estados hegemônicos e dos organismos internacionais econômicos sobre os Estados andinos e, de resto, sobre toda a América do Sul, o que contribuiu, especialmente a partir do denominado Consenso de Washignton, para a implantação de medidas que tiveram como efeito a readequação do sistema-mundo/colonial e a manutenção dos seus desvios na região ${ }^{46}$.

in intellectual property but not in other areas of regional integration? (...) We inquire, first, into the creation and protection of IP rights for private parties under the Andean legal system; second, into whether national actors - in particular administrative agency officials - habitually implement Andean IP rules as interpreted by Andean judges; and third, into whether individual member countries comply with ATJ rulings in the face of contrary pressure by foreing interests (principally the United States and American pharmaceutical companies" HELFER, Laurence et al. Op. cit., p. 3.

46 Sobre este aspecto, aponta Helfer: "By the late 1980s, a prevaisve crisis in Latin America had pushed the Andean Pact to the brink os falilure. Using the substantial economic leverage that crisis engendered, the World Bank, the Inter-American Development Bank, and Internactional Monetary Fund (IMF) pressed Andean governments to adopt a broad array of liberalizing and deregulatory reforms. These reformsm known as the 'Washington Consensus' engendered fundamental changes in how Andean countries regulated their economies. National governments - acting on their own and through Andean institutions - adopted major policy reforms to achieve open, market-bases economies and creadted nes 


\section{CONCLUSÃO}

A análise das Interpretações Prejudiciais proferidas pelo TJA permitiu, finalmente, enfrentar as questões inicialmente propostas no trabalho de investigação jurídica e dimensionar, pela atuação dos seus tribunais manifesta em sua jurisprudência, a natureza do direito de integração nos blocos comunitários sul-americanos, especialmente a Comunidade Andina, cujas instituições mais se assemelham a União Europeia.

As conclusões que emergiram nos indicam a necessidade de repensar qual a arquitetura institucional que seria mais adequada à efetivação do direito de integração sul-americano em face à evidência de que os tribunais comunitários, neste estado da arte, demonstraram não ser essenciais ao projeto de regionalização.

O reenvio das questões suscitadas perante órgãos jurisdicionais nacionais ao TJA, conforme tem sido utilizado, não demonstrou tratar-se de uma prestação jurisdicional eficiente e adequada às partes litigantes, em relação àquela já provida pelo "juiz", no caso o árbitro das Juntas Julgadoras sobre propriedade industrial, posto que onera e retarda a prestação jurisdicional, sem que possa garantir uma administração da justiça de forma mais adequada e eficiente.

O procedimento da Interpretação Judicial, com o reenvio necessário de toda matéria ao TJA, inclusive aquelas já submetidas e com interpretação consolidada, tem levado a uma profusão de decisões de conteúdo idêntico sobre direito de marcas e patentes sem incorporar ou traduzir inovações de fato significativas à cooperação jurídica comunitária.

Esperava-se que o TJA, em face das características peculiares da região, ao interpretar e esclarecer o direito andino pudesse inoválo, conferindo-lhe caracteres próprios em relação aos institutos europeus transplantados. Por enquanto, não foi possível identificar na jurisprudência comunitária sula-americana, tal como ocorreu naquela produzida pelo TJE que proferiu, em Interpretações Prejudiciais,

institutions staffed by Western-educated professionals who endorsed these goals". HELFER, Laurence et al. Op. cit., p. 7-8. Mais adiante: "In the early 1990s, member states shifted course and adopted four Decisions that mandated progressively higher levels os IP protection, These new regional laws refleted the market liberalization goals of the later phases of the Washington Consensus. But other factors reinforced the impetus for change: the inclusion of IP rules in the Uruguay Round of multilateral trade negotiations and threats of trade sanctions by the United States. HELFER, Laurence et al. Op. cit., p. 10. (...) "As of 1994, although Andean IP rules were consistent with TRIPS, they fell short of the demands of U.S IP rights holders for more capacious IP protection. The United States and its IP industries responded by pressuring individual Andean countries to negociate bilateral treaties and to enact domestic laws containing enhanced IP rules. These strategies caused some national executives to defect from Andean rules, but (...) the ATJ and the General Secretariat proved to be hospitable forums for the region's generic drug industry to challenge these defections as violations of Andean Law. However, compliance with the ATJ rulings upholding these challenges would not have occurred without the support of domestics IP agenciese, whose restructuring was also a product of the Washington Consensus reforms HELFER, Laurence et al. Op. cit., p.10-11. 
decisões paradigmáticas ao seu Direito Comunitário ${ }^{47}$.

Nesse aspecto, apenas o processo 60-IP-2012 é representativo, por suscitar, por iniciativa da Organização Nacional Indígena da Colômbia (ONIC), questões relativas à biodiversidade e ao patrimônio comum dos povos originários. No entanto, a autora, ao impugnar o registro da marca pretendida, não logrou vencer sua demanda, pois a pretensão do particular interessado foi reconhecida como legítima, embora sem garantir-lhe exclusividade no uso das expressões Coca Indígena e Coca Zagradha ${ }^{48}$.

De resto, as Interpretações Prejudiciais demonstraram ser praticamente inócuas, pois tratam, essencialmente, de questões já pacificadas pela doutrina e jurisprudência européias, confirmadas, com pequenas nuances de diferença, pelos juízes da CAN. Desta forma, fica comprometida sua contribuição ao desenvolvimento da cooperação judicial vertical ou horizontal, pois raramente atendem aos tribunais locais para esclarecer questões processuais relativas ao processo internacional ou comunitário, este, um ramo jurídico novo para os poderes judiciários nacionais.

Frente a esta situação, é imprescindível repensar a estrutura, o processo e a composição, tanto do TJA como do TPRM, pois até o momento, não tem cumprido o papel que deles se poderia esperar.

\section{RESUMO BIOGRÁFICO}

Cynthia Soares Carneiro é Doutora em Direito Internacional pela Faculdade de Direito da Universidade Federal de Minas Gerais. Professora de Direito Internacional e de Direito da Integração no curso de graduação e pós-graduação strictu senso da Faculdade de Direito de Ribeirão Preto/USP.

\section{REFERÊNCIAS BIBLIOGRÁFICAS}

ALTER, Karen; HELFER, Laurence R.; SALDÍAS, Osvaldo. "Transplanting the European Court of Justice: the experience of the Andean Tribunal of Justice". Oñati International Institute for the Sociology of Law. Social-Legal Series. 2011, vol 1, no 4, p. 1-30.

BARACHO, José Alfredo de Oliveira. "O princípio de subsidiariedade: conceito e revolução”. Revista de Direito Administrativo. 1995, p. 21-54.

COLISTETE, Renato Perim. "O desenvolvimentismo cepalino:

47 Por exemplo, o caso Van Gend em Loos, no qual o TJE proclamou o princípio da aplicação imediata do Tratado de Roma e das regras de livre-mercado no ordenamento jurídico de cada Estado-Membro da CEE; e o caso Simenthal, no qual foi fixado o princípio da aplicação direta e imediata do direito comunitário pelo juiz nacional, são clássicos.

48 Disponível em: <http://www.tribunalandino.org.ec/sitetjca1/index.php?option=com filecabinet\&view=files\&id=1\&Itemid=92> [acesso em 15.fev.2017]. 
problemas teóricos e desenvolvimento no Brasil". Revista do Instituto de Estudos Avançados. 2001, vol 15, nº 41.

GABARDO, Emerson. Interesse público e subsidiariedade: o Estado e a sociedade civil para além do bem e do mal. São Paulo: Fórum, 2009.

HELFER, Laurence R. ALTER, Karen; GUERZOVICH, Florencia. "Islands of effective international adjucation: constructing an intellectual property rule of law in the Andean Community". The American Journal of International Law. 2009, vol 103, nº 1, p. 1-47.

LÁZARO, Alicia Chicharro. El Principio de Subsidiariedad en la Unión Europea. Madrid: Aranzadi, 2001.

MAGALHÃES, J. L. Q. Pacto Federativo. Belo Horizonte: Mandamentos, 2002.

MAGALHÃES, José Luiz Quadros; ROCHA, Carlos Alberto Vasconcelos. O município e a construção da democracia participativa. Belo Horizonte: Mandamentos, 2006.

MERCOSUL. TRIBUNAL PERMANENTE DE REVISÃO. "Norte S.A. Imp. Exp. c/ Laboratorios Northia Sociedad Anónima, Comercial, Industrial, Financiera, Inmobiliaria y Agropecuaria s/ Indemnización de Daños y Perjuicios y Lucro Cesante", solicitud cursada por la Corte Suprema de Justicia del Paraguay con relación a los autos del Juzgado de Primera Instancia en lo Civil y Comercial del Primer Turno de la jurisdicción de Asunción. Opinião Consultiva n 1/2007.

PEREZ, Cecília Falcone. "Ecuador: new intellectual property Law" [online]. Grain. 1998, vol 28 [acesso em 30. jul.2013]. Disponível em: $<$ http://www.grain.org/article/entries/1915-ecuador-new-intellectualproperty-law>

QUADROS, Fausto de. O princípio da subsidiariedade no direito comunitário após o tratado da União Européia. Coimbra: Almedina, 1995.

QUIJANO, Aníbal. Colonialidade do poder, eurocentrismo e América Latina. A colonialidade do saber: eurocentrismo e ciências sociais. Perspectivas Latino-Americana. Buenos Aires: Clacso, 2005, p. 117-142.

QUIJANO, Aníbal. "Os fantasmas da América Latina”. In: NOVAES, Adauto (ed.). Oito visões da América Latina. SP: Senac, 2006, p. 49-85.

WALLERSTEIN, Immanuel. Capitalismo histórico e civilização capitalista. SP: Contraponto, 2001. 